\title{
Dolomitization of the lower St. George Group on the Northern Peninsula in western Newfoundland: implications for lateral distribution of porosity
}

\author{
K. AZMY \\ Department of Earth Sciences \\ Memorial University of Newfoundland \\ St. John's, NL A1B $3 X 5$ \\ kazmy@mun.ca
}

\author{
J. CONLIFFE \\ Department of Earth Sciences \\ Memorial University of Newfoundland \\ St. John's, NL A1B $3 X 5$
}

\begin{abstract}
The Watts Bight Formation constitutes the lowermost part of the St. George Group in western Newfoundland. On the Northern Peninsula, it consists of Tremadocian (lower Ordovician) shallow marine platform carbonates (approximately $50 \mathrm{~m}$ thick). Dolomitization is extensive throughout the formation except for its topmost part. Petrographic examinations suggest that the succession was affected by at least three successive phases of dolomitization, which influenced secondary porosity. These phases have crystal-size ranges of approximately 4 to $50 \mu \mathrm{m}$ (earliest sub- to euhedral dolomite D1), 50 to $200 \mu \mathrm{m}$ (eu- to subhedral D2), and $300 \mu \mathrm{m}$ to $3 \mathrm{~mm}$ (anhedral saddle dolomite D3), respectively. They occur as replacement and/or pore-filling cements and exhibit dull (D1 and D3) to zoned (D2) luminescence under the cold cathodoluminoscope. The D2 phase is the dominant dolomite while the other two phases are rare.

Microthermometric measurements of the primary two-phase fluid inclusions in D2 (homogenization temperatures up to $157^{\circ} \mathrm{C}$ and salinity estimates up to 24.3 eq. $\mathrm{wt} \% \mathrm{NaCl}$ ) suggest that it formed under relatively deep burial conditions. This is supported by the petrographic character (eu- to subhedral relatively big crystals) and geochemical composition (depleted $\delta^{18} \mathrm{O}$ mean value of $-8.7 \pm 1.2 \%$ VPDB and low $\mathrm{Sr}$ contents of $68 \pm 30 \mathrm{ppm}$ ) of the D2 phase. Thin-section examination suggests that porosity is dominantly intercrystalline and associated with the D2 phase. Visual estimates suggest that porosity varies from $<1 \%$ in most of the formation to approximately $10 \%$ in two horizons, each approximately $2 \mathrm{~m}$ thick, at approximately $10 \mathrm{~m}$ and $20 \mathrm{~m}$ from formation base. Correlations with the equivalent Watts Bight Formation section in the Isthmus Bay (300 km to South) reveal porous intervals at comparable stratigraphic levels. Also the geochemical results and microthermometric measurements suggest that D2 in the Northern Peninsula section was formed from hotter fluids under relatively more reducing conditions relative to their Isthmus Bay counterparts. The porous zones seem to be associated with fluctuations in sea-level marked by negative shifts in the $\delta^{13} \mathrm{C}$ profile.
\end{abstract}

\section{RÉSUMÉ}

La Formation de Watts Bight constitue l'unité la plus basse du Groupe de St.George dans l'ouest de Terre-Neuve. Dans la péninsule Great Northern, elle est composée de carbonates de plateaux marins (d'environ $50 \mathrm{~m}$ d'épaisseur) peu profonds du Trémadocien (Ordovicien inférieur). La dolomitisation est considérable dans toute la formation, à l'exception de sa partie la plus élevée. Les analyses pétrographiques donnent à penser qu'au moins trois épisodes de dolomitisation ont affecté la succession, ce qui a influencé la porosité secondaire. La taille des cristaux de ces épisodes de dolomitisation varie de $4 \mu \mathrm{m}$ à $50 \mu \mathrm{m}$ (dolomite $\mathrm{D} 1$ précoce de subautomorphe à automorphe), de $50 \mu \mathrm{m}$ à $200 \mu \mathrm{m}$ (D2 automorphe à subautomorphe) et de $300 \mu \mathrm{m}$ à $3 \mathrm{~mm}$ (dolomite D3 en selle anédrique), respectivement. Ils se présentent sous forme de remplacement et/ou de cimentation d'espaces intergranulaires et ils révèlent une luminescence variant de terne (D1 et D3) à zonée (D2) sous le cathodoluminoscope à froid. L'épisode D2 représente la dolomite dominante, tandis que les deux autres épisodes sont rares.

Les mesures microthermométriques des inclusions fluides primaires biphasées dans D2 (température d'homogénéisation allant jusqu'à $157^{\circ} \mathrm{C}$ et les salinités allant jusqu'à $24,3 \%$ équivalent en poids $\mathrm{NaCl}$ ), suggèrent que la dolomite se soit formée dans des conditions d'enfouissement relativement profond. Ce qui précède s'appuie sur le caractère pétrographique (c.-à-d. des cristaux automorphes à subautomorphes relativement gros) et la composition géochimique (valeur appauvrie en $\delta^{18} \mathrm{O}$ valeur moyenne de $-8,7 \pm 1,2 \%$ VPDB et faible contenu en $\mathrm{Sr}$ de $68 \pm 30 \mathrm{ppm}$ ) de l'épisode de D2. L'observation des lames minces donne à penser que la porosité est à dominante intercristalline et associée à l'épisode D2. Selon les 
estimations visuelles, la porosité varie de moins de $1 \%$ pour la plus grande partie de la formation, jusqu'à environ $10 \%$ dans deux horizons d'à peu près $2 \mathrm{~m}$ d'épaisseur chacun, et cela de $10 \mathrm{~m}$ à $20 \mathrm{~m}$ à partir de la base de la formation. Les corrélations avec la section équivalente de la Formation de Watts Bight dans Isthmus Bay (à $300 \mathrm{~km}$ au sud) révèlent des intervalles poreux aux niveaux stratigraphiques comparables. De plus, les résultats géochimiques et les mesures microthermométriques suggèrent que D2 dans la section de la péninsule de Great Northern se soit formée au moyen de fluides plus chauds dans des conditions plus réductrices par rapport aux dolomites correspondantes d'Isthmus Bay. Les zones poreuses semblent associées aux fluctuations du niveau marin marquées par des décalages négatifs dans le profil des valeurs $\delta^{13} \mathrm{C}$.

Michel Ory

\section{INTRODUCTION}

The presence of major hydrocarbon accumulations in dolomitized horizons of Paleozoic carbonates on the eastern Laurentian margin has directed the focus of some reservoir characterization studies towards western Newfoundland (cf. Haywick, 1984; Lane, 1990; Cooper et al., 2001; Lavoie et al., 2005, Azmy et al., 2008, 2009, Conliffe et al., 2009). Hydrothermal dolomitization of the carbonates has been found associated with enhancement of porosity in the reservoir rocks of the Appalachians and the adjacent St. Lawrence Platform domain, including the Lower Ordovician Romaine Formation of the Anticosti Basin (Lavoie et al., 2005), the Lower Silurian La Vieille and Sayabec formations in Gaspé and northern New Brunswick (Lavoie and Morin, 2004; Lavoie and Chi, 2006), and the Upper Ordovician Trenton-Black River dolomites in New York and Anticosti (Smith, 2006).

Earlier field studies of the Lower Ordovician St. George Group carbonates in western Newfoundland indicated high porosity horizons associated with hydrothermal dolomitization (Azmy et al., 2008, 2009; Greene, 2008; Conliffe et al., 2009; Conliffe et al., 2010). In western Newfoundland, organic-rich shale in the Green Point Formation (Cow Head Group) is a possible source rock (Cooper et al., 2001). Impermeable layers overlying (e.g. Table Point Formation limestone of the Table Head Group) or interbedded with the porous layers (e.g. impervious dolomicirite and limestone layers) may be a good seal (Azmy et al., 2008, 2009; Greene, 2008; Conliffe et al., 2009). These are critical elements for an effective hydrocarbon system to be associated with the St. George Group dolomites. Also, structural traps likely developed during the Middle Devonian Acadian Orogeny (Baker and Knight, 1993; Fowler et al., 1995; Stockmal et al., 1998; Cooper et al., 2001; Knight et al., 2008). A discovery well on Port au Port Peninsula produced about $3400 \mathrm{~m}^{3}$ of oil from the uppermost St. George carbonates between 1995 and 2001 (Azmy et al., 2008).

This report deals with the Watts Bight Formation, part of the St. George Group on the Northern Peninsula, western Newfoundland. Objectives of this investigation are (1) to study the origin of dolomitization in the Watts Bight Formation to understand its controls on porosity development, and (2) to investigate the lateral distribution of the dolomite-associated porous zones with their counterparts in the outcrop section on the Port au Port Peninsula, $300 \mathrm{~km}$ away.

\section{Geologic SetTing ANd LithostratigRaPhy}

The geologic setting of the St. George Group has been discussed by several authors (e.g. Wilson et al., 1992; Knight et al., 1991; Cooper et al., 2001; Knight et al., 2007, 2008). The Watts Bight Formation is the lowermost part of the St. George Group, which extends across western Newfoundland (Fig. 1) and was deposited on the eastern margin of Laurentia during the Early Ordovician (Fig. 2). The Laurentian paleoplate developed by active rifting around 570 to $550 \mathrm{Ma}$ (Cawood et al., 2001) and a pre-platform shelf was formed and covered by clastics (James et al., 1989). A major transgression flooded the Laurentian platform margin, resulting in the accumulation of thick carbonate platform deposits (Wilson et al., 1992; Knight et al., 2007, 2008; Smith and Rasmussen, 2008). In western Newfoundland, Middle and Late Cambrian platform deposits are dominated by high-energy carbonates. These are succeeded by Early to earliest Middle Ordovician low-energy carbonates of the St. George Group (cf. Knight et al., 2007, 2008). Compression associated with the Taconic Orogeny led to uplift and erosion of the St. George carbonate platform and development of the regional St. George Unconformity, which marks the uppermost boundary of the group (cf. Knight et al., 1991; Knight et al., 2007).

The lithostratigraphy and cyclic peritidal deposits of the St. George Group have been exhaustively studied and refined by several authors (e.g. Pratt and James, 1986; Knight and James, 1987; Knight, 1991; Cooper et al., 2001; Knight et al., 2007, 2008). The St. George Group consists of Lower Ordovician (Tremadoc-Arenig) platform carbonates which, from bottom to top, include the Watts Bight, Boat Harbour, Catoche, and Aguathuna formations (Fig. 2). Earlier studies investigated the Watts Bight Formation carbonates in well-exposed, complete outcrop sections in Isthmus Bay, southwestern Newfoundland (Knight et al., 2008; Azmy et al., 2009; Conliffe et al., 2009). The current study deals with data from Borehole 12P/1-12 on the Northern Peninsula (Fig. 1) and compares them with the earlier outcrop data.

The Watts Bight Formation overlies unconformably the peritidal carbonates of the Upper Cambrian to Lower Ordovician Berry Head Formation of the Port au Port Group (Knight et al. 2008). On the Northern Peninsula, the Watts Bight Formation is completely dolomitized to a sucrosic dolomite that retains some of the sedimentary features of the precursor limestone (Knight 


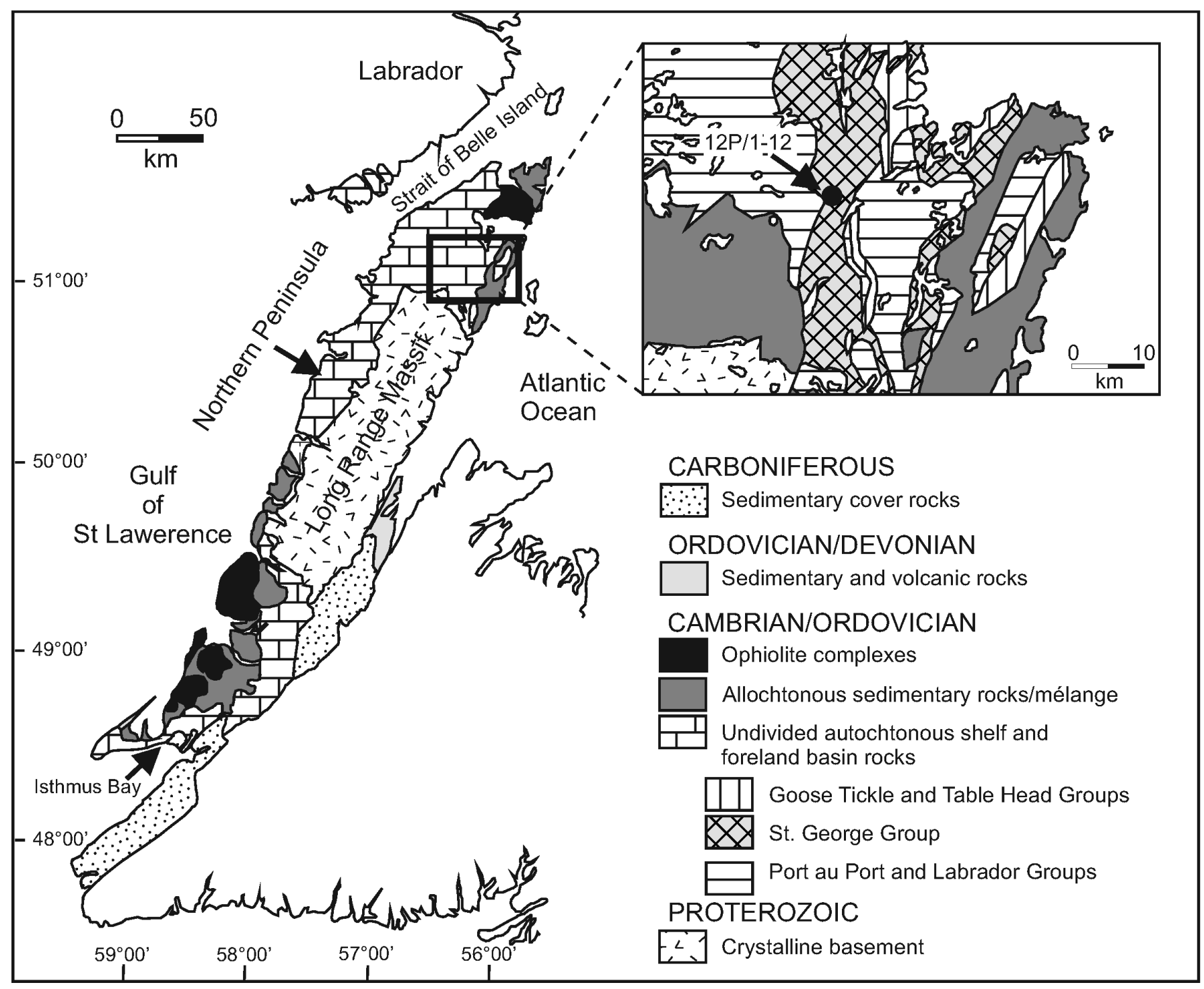

Fig. 1. Map of western Newfoundland showing approximate locations of the investigated drill hole 12P/1-12 on the Northern Peninsula and the Isthmus Bay outcrop in the Port au Port Peninsula (modified from Zhang and Barnes, 2004). See text for details.

et al., 2008). Knight et al. (2008) described two sequences of low-energy bioturbated and mound carbonates overlain by higher energy facies with mounds and grainstones, which generally mimic the succession of the outcrop section (approximately $70 \mathrm{~m}$ thick) on the Port au Port Peninsula, approximately $300 \mathrm{kms}$ to the south. This packaging may reflect the transgression and drowning of a shallow shelf, followed by gradual accretion into the tidal zone (Knight et al., 2008).

\section{METHOdOLOGY}

The complete section of the Watts Bight Formation (48 m) was examined from drillhole $12 \mathrm{P} / 1-12$ near the north end of the Northern Peninsula (Fig. 1; 51 $08^{\prime} 23^{\prime \prime}$ N, 56 $16^{\circ} 54^{\prime \prime}$ W; NAD 83). This core was drilled by Shell Canada Ltd. in 1976 as part of a Pb-Zn exploration program (Knight, 1996, http:// gis.geosurv.gov.nl.ca/resourceatlas/viewer.htm).
Drill logs and visual inspection of the core confirms that it is completely dolomitized, with intercrystalline and vuggy porosity associated with several horizons. Closely-spaced samples were collected (with sampling interval as narrow as $2 \mathrm{~m}$, Appendix 1) from the core. Petrographic thin sections of the sample slabs were examined under standard polarizing microscope and cathodoluminoscope (CL) and stained with Alizarin Red-S and potassium ferricyanide solutions. A mirror-image slab of each thin section was also prepared and polished to be utilized for microsampling. Cathodoluminescence was performed using an ELM-3R cold cathode instrument operated at approximately $12 \mathrm{kV}$ accelerating voltage and approximately $0.7 \mathrm{~mA}$ gun current intensity. Microthermometric fluid-inclusion analyses were performed on double polished wafers (approximately100 $\mu \mathrm{m}$ thick) using a Linkam THMSG600 heating-freezing stage. Calibration with precision of $\pm 0.2^{\circ} \mathrm{C}$ at $-56.6^{\circ} \mathrm{C}$ and $\pm 1^{\circ} \mathrm{C}$ at $300^{\circ} \mathrm{C}$ was conducted using synthetic 


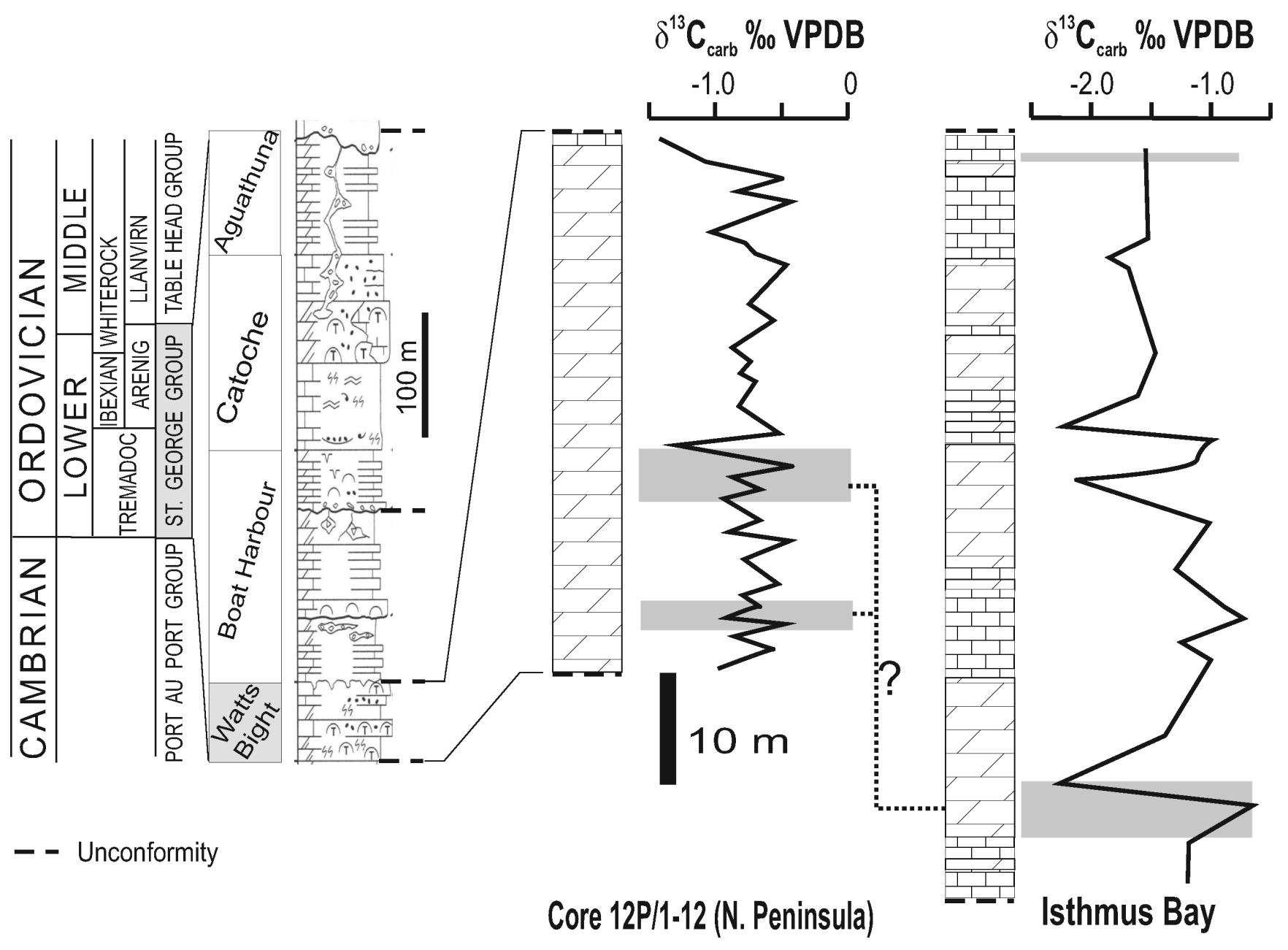

Fig. 2. Stratigraphic framework of the St. George Group (details from Knight et al., 2008) and Watts Bight Formation (core details available at http://gis.geosurv.gov.nl.ca/resourceatlas/viewer.htm). Also shown are carbon isotope profiles of the Watts Bight Formation from Core 12P/1-12 on the Northern Peninsula and the equivalent section at Isthmus Bay, $300 \mathrm{~km}$ to the south on the Port au Port Peninsula. Gray bars mark the approximate levels of the porous horizons (porosity $=4-7 \%$ ). The C-isotope profile at Isthmus Bay is reproduced from Conliffe et al. (2009) and Azmy and Lavoie (2009).

$\mathrm{H}_{2} \mathrm{O}$ and $\mathrm{CO}_{2}$ fluid inclusion standards. The initial melting temperatures $\left(\mathrm{T}_{\mathrm{i}}\right)$, last ice melting $\left(\mathrm{T}_{\mathrm{m} \text { (ice) }}\right)$ and the homogenization temperature $\left(\mathrm{T}_{\mathrm{h}}\right)$ were measured in primary two-phase (liquid + vapour) inclusions following procedures outlined by Shepherd et al. (1985). Aqueous fluid salinities were calculated using $T_{m}$ (ice) and the equation of Bodnar (2003).

Polished slabs were washed with deionized water and dried overnight at $50^{\circ} \mathrm{C}$ prior to microsampling. Approximately $4 \mathrm{mg}$ were microsampled from the cleaned slabs with a low-speed microdrill. For C- and O-isotope analyses, about $200 \mu \mathrm{g}$ of powder sample was reacted in an inert atmosphere with ultra-pure concentrated (100\%) orthophosphoric acid at $70^{\circ} \mathrm{C}$ in a Thermo-Finnigan Gasbench II. The $\mathrm{CO}_{2}$ produced from the reaction was automatically flushed through a chromatographic column and delivered to the source of a ThermoFinnigan DELTA V plus isotope ratio mass spectrometer in a stream of helium, where the gas was ionized and measured for isotope ratios. Uncertainties of better than $0.1 \%$ o $(2 \sigma)$ for the analyses were determined by repeated measurements of NBS-19 $\left(\delta^{18} \mathrm{O}=-2.20 \%\right.$ and $\delta^{13} \mathrm{C}$ $=+1.95 \%$ vs. VPDB $)$ and L-SVECS $\left(\delta^{18} \mathrm{O}=-26.64 \%\right.$ and $\delta^{13} \mathrm{C}=-46.48 \%$ vs. VPDB) as well as internal standards during each run of samples.

For elemental analyses, a subset of sample powder was digested in $2.5 \%(\mathrm{v} / \mathrm{v})$ pure $\mathrm{HNO}_{3}$ acid and analysed for $\mathrm{Ca}$, $\mathrm{Mg}, \mathrm{Sr}, \mathrm{Mn}$ and Fe (Coleman et al., 1989) using a HP 4500plus ICPMS at Memorial University of Newfoundland. The relative uncertainties of these measurements are less than $4 \%$. Calculations of major and trace element concentrations are based on an insoluble residue-free basis $(100 \%$ soluble dolomite or calcite).

\section{RESULTS}

\section{Petrography}

The Watts Bight lithofacies of the Northern Peninsula of western Newfoundland are similar to those of the Isthmus Bay outcrop section on the Port au Port Peninsula. They are mainly 


\section{SYMBOLS}

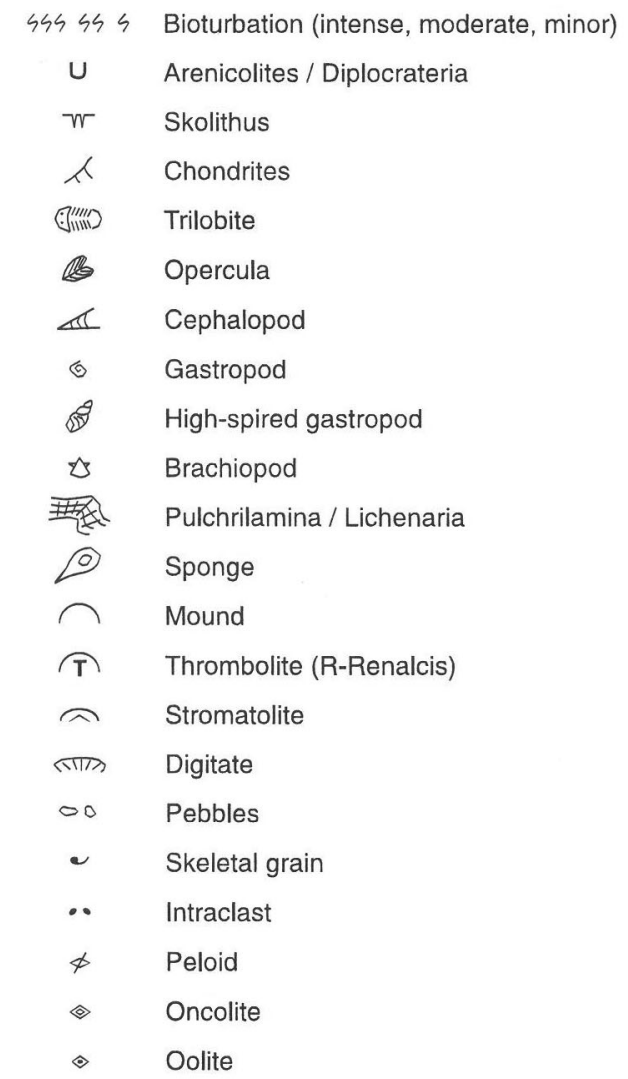

\begin{tabular}{|c|c|}
\hline we & Grainstone lense \\
\hline 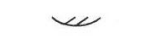 & Trough cross bedding \\
\hline$\ldots$ & Planar cross bedding \\
\hline$\approx$ & Uneven stylo-thin stratification \\
\hline$=\mathrm{mm} \mathrm{cm}$ & Planar lamination, thin bedding \\
\hline$\approx \mathrm{mm} \mathrm{cm}$ & Undulose lamination, thin bedding \\
\hline$\Phi$ & Limestone nodule \\
\hline - & Chert \\
\hline$\frown$ & Chert outlining mounds \\
\hline$\checkmark$ & Mudcrack \\
\hline 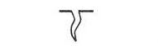 & Fissure crack \\
\hline$\infty$ & Fenestra \\
\hline 公 & Tepee \\
\hline n & Ripple mark \\
\hline$\infty$ & Flaser \\
\hline$\infty$ & Dolostone lens \\
\hline se & Nodular/parted \\
\hline$v$ & Gutter cast \\
\hline$m$ & Hardground \\
\hline 2 & Convoluted \\
\hline$\Delta \nabla$ & Breccia \\
\hline$+\infty$ & Vug \\
\hline 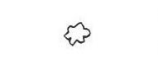 & $\begin{array}{l}\text { Cauliflower nodule (cte-calcite, } \\
\text { dte-dolomite, Q-quartz) }\end{array}$ \\
\hline$\Leftrightarrow$ & Geopetal cavity \\
\hline
\end{tabular}

\section{LITHOLOGY}

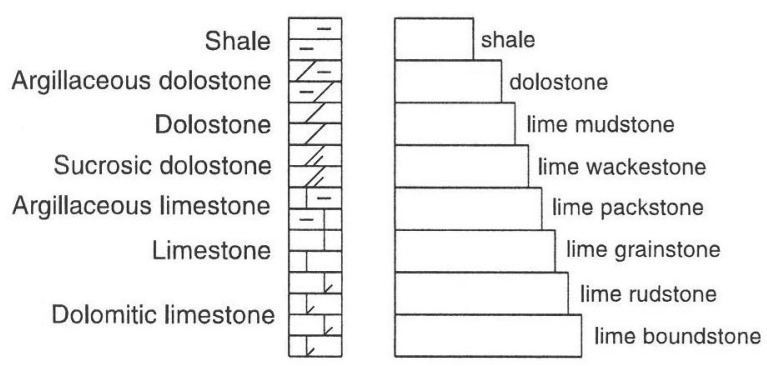

Fig. 2 Legend.

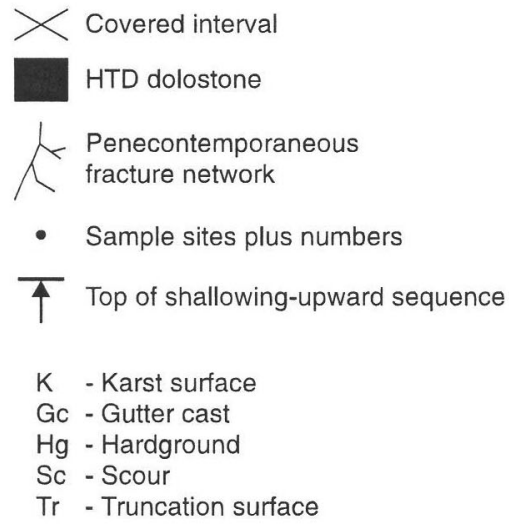

microbial lime mudstones and wackstones, but rarely skeletal and latest coarse (cm scale) clear blocky cements (C3) filling grainstones (cf. Knight et al., 2008; Azmy et al., 2009; Conliffe fractures and vugs (Fig. 3a). However, the meteoric cements et al., 2009). Petrographic analysis in the current study also (C2) that have been documented in other formations of the St. reveals similar calcite and dolomite phases for the two areas George Group (e.g. Azmy et al., 2008, 2009) are very difficult (Azmy et al., 2009; Conliffe et al., 2009). The calcite genera- to recognize in the currently investigated sequence. The prestions, from the oldest to the youngest, are marine micritic and ence of calcitic carbonate phases is generally rare because of microbial mud (C1, Knight et al., 2008) with skeletal fragments the pervasive dolomitization. Calcite phases (C1 and C3) 

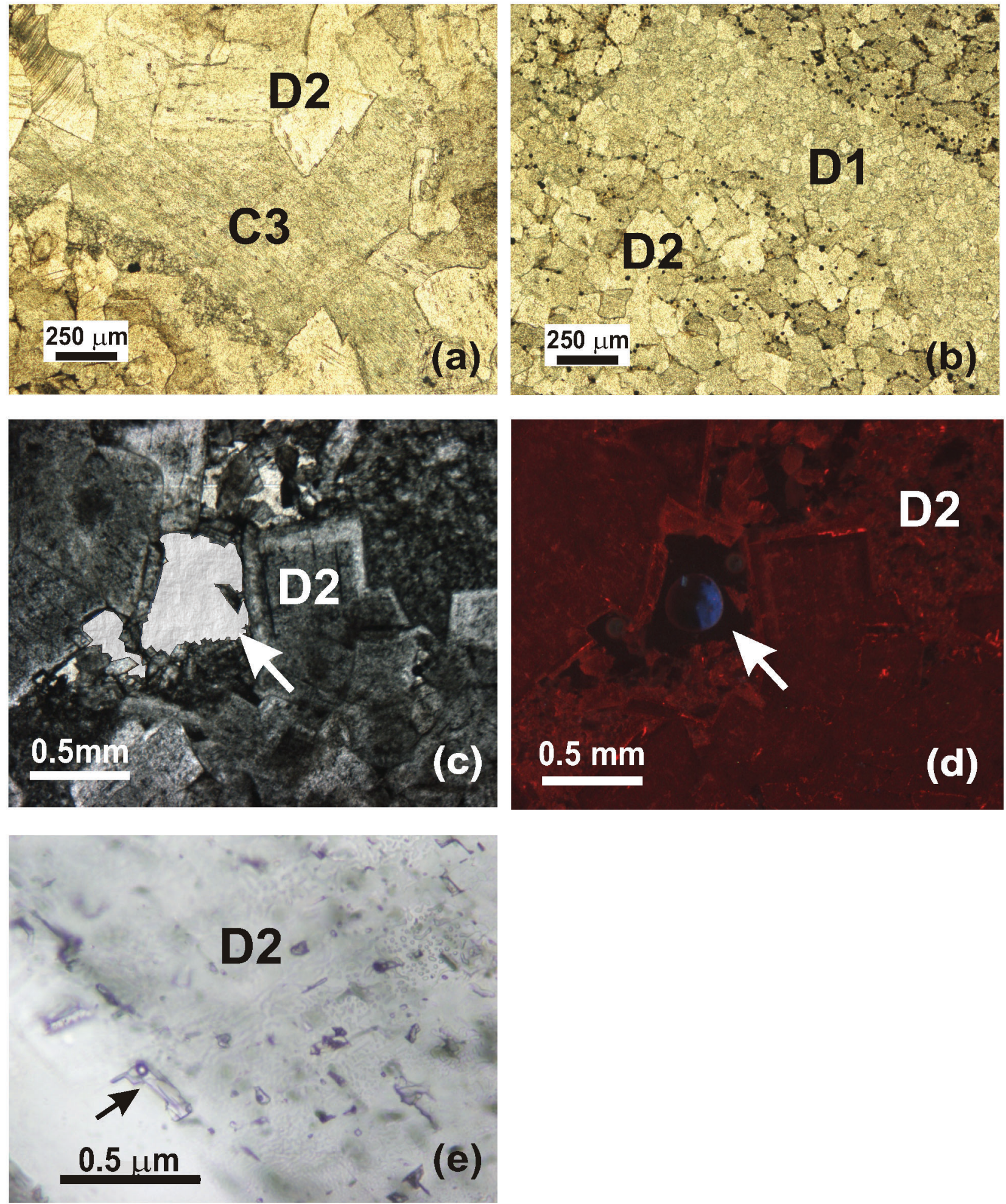

Fig. 3. Photomicrographs of the main petrographic characteristics of the Watts Bight Formation dolomites in the investigated core section. Scale bars as indicated. (a) Pore-filling C3 (plane polarized, Sample P228). (b) D1 spots mixed with D2 (plane polarized; Sample P196). (c) Intercrystalline porosity (arrow) associated with euhedral D2 crystals showing cloudy cores and clear rims (plane polarized; Sample P216). (d) Cathodoluminoscope image of (c) showing zoned luminescence in D2. (e) Biphase inclusions in D2 dolomite rhomb showing an inclusion elongated in the direction of growth of the dolomite rhomb (arrow). The lack of fractures around the inclusion argues for its primary nature and against fluid leaking. 
appear dull to non-luminescent under the cold cathodoluminoscope.

Dolomitization is a major diagenetic process in the Watts Bight. Petrographic and cathodoluminescence examination reveal three generations of dolomite, which, from oldest to youngest, are: Dolomite 1 (D1, dolomicrite; Fig. 3b); Dolomite 2 (D2, equant replacive dolomite, Fig. 3a); and Dolomite 3 (D3, latest large equant pore-filling to replacive saddle dolomite).

Dolomite 1 (Fig. 3b) consists of sub- to euhedral (planar-s mosaic of tight interlocking) inclusion-rich pervasive dolomite (cf. Sibley, 1982; Budd, 1997; Warren, 2000) with crystal sizes between 10 and $50 \mu \mathrm{m}$, and exhibits dull luminescence (cf. Machel and Mountjoy, 1986, 1990; Azmy et al., 2009; Conliffe et al., 2009) under CL examination. The scarcity of limestone beds on the Northern Peninsula suggests that dolomitization was more extensive there than on the Port au Port Peninsula. Unlike the Watts Bight Formation carbonates in Isthmus Bay, dolomicrite (D1) is very rare in the sequence on the Northern Peninsula and mingles with the D2 crystals so that it is very hard to microsample.

Dolomite 2 is the most abundant phase, making up to $95 \%$ of the investigated Watts Bight carbonates (e.g. Conliffe et al., 2009), and consists of coarse, equant, sub- to euhedral crystals (planar-e to planar-s) that developed during progressive replacement or recrystallization (e.g. Lee and Friedman, 1978; Lonnee and Machel, 2006; Azmy et al., 2009; Conliffe et al., 2009; Lavoie et al., 2010). The crystals vary in size between about 50 and $250 \mu \mathrm{m}$ and exhibit cloudy cores with clear rims (e.g. Azmy et al., 2008, 2009; Kırmac1, 2008; Rameil, 2008; Conliffe et al., 2009) under plane polarized light (Fig. 3b-d) and concentric zoned luminescence under CL (Fig. 3d). The D2 crystals may exhibit undulose extinction, particularly the large crystals (approximately $200 \mu \mathrm{m}$ ), and are crosscut by solution seams and microstylolites, interpreted to reflect the shallow burial environment. Intercrystalline porosity (Ø), with visual estimates of up to $10 \%$, has been found associated with D2 (Fig. 3c) in only a few horizons of the Watts Bight carbonates (e.g. 15 to $20 \mathrm{~m}$ from the base) on the Northern Peninsula.

D3 is pore-filling, coarse, sub- to anhedral crystals (approximately $3 \mathrm{~mm}$ ) of saddle dolomite that exhibit undulose extinction and dull CL similar to the features of D3 crystals in the equivalent Isthmus Bay outcrop section (e.g. Azmy et al., 2009; Conliffe et al., 2009). Like C3, D3 is very rare in the investigated core.

\section{FLUID INCLUSIONS}

Fluid inclusions were examined in D2 dolomite rhombs. Care was taken to study fluid inclusions hosted in the clusters in the core of dolomite crystals or elongate inclusions aligned parallel to growth direction in the clear rims, which are used as evidence for primary origin (Goldstein and Reynolds, 1994). Microthermometric measurements of primary two-phase fluid inclusions from D2 (Fig. 3e) and estimated salinity (Bodnar, 2003) are summarized in Table 1 and Figure 4. The measurements of homogenization temperatures $\left(T_{h}\right.$, minimum estimate of entrapment temperature) and melting points $\left(\mathrm{T}_{\mathrm{m}}\right)$ were taken from inclusions hosted in crystals covering the entire crystal size spectrum. Distribution patterns of $T_{h}$ data (Fig. 4a) show that the inclusions in the outer clear zones indicate generally higher temperatures $\left(140.1 \pm 6.1^{\circ} \mathrm{C}, n=27\right)$ than those from cores of dolomite crystals or from smaller crystals $\left(107.3 \pm 10.6^{\circ} \mathrm{C}\right.$, $n=33$ ). The calculated salinities (Fig. 4b) do not follow the same trend $(23.4 \pm 0.7$ eq. wt $\% \mathrm{NaCl}, n=18$ and $23.0 \pm 0.7$ eq. wt $\% \mathrm{NaCl}, n=13$, respectively).

The mean values of $\mathrm{T}_{h}$ for D2 in Watts Bight dolomites on the Northern Peninsula are higher than their counterparts documented for the Isthmus Bay section $\left(79.7 \pm 13.4^{\circ} \mathrm{C}, n=58\right.$, Conliffe et al., 2009) although the estimated mean salinity value for the latter $(17.5 \pm 4.5 \%, n=31$, Conliffe et al., 2009) is not significantly different.

\section{GEOCHEMISTRY}

\section{Major and Trace Elements}

Table 2 summarizes major and trace element concentrations in carbonate phases of the Watts Bight Formation in the Northern Peninsula. Elemental geochemical data for D1 were excluded because D1 was rare and found only mixed with D2, so that it was impossible to microsample without contamination. The geochemical analyses (Table 2, Appendix1) suggest that D2 in Watts Bight Formation on the Northern Peninsula (56.5 $\pm 6.7 \%)$ is slightly less calcitic compared to its equivalents $(59.3 \pm 3.7 \%)$ at Isthmus Bay (Conliffe et al., 2009) and has lower Sr (68 \pm 30 ppm, $n=20$ vs. $97 \pm 93$ ppm, $n=20$ ). By comparison, Fe (1548 \pm 1552 ppm, $n=20$ vs. $639 \pm 268$ ppm, $n=20)$ and Mn concentrations ( $97 \pm 33$ ppm, $n=20$ vs. $73 \pm 38$ ppm, $n=20)$ are higher on the Northern Peninsula. Geochemical elemental composition of the only D3 sample extracted indicates approximately similar composition to that of D2 but with clearly higher Mn contents.

\section{Oxygen and Carbon Isotopes}

Generally speaking, the $\delta^{13} \mathrm{C}$ and $\delta^{18} \mathrm{O}$ values of the carbonates in the investigated core section (Table 2 and Fig. 5) decrease from $\mathrm{C} 1$ ( $-1.4 \%$ VPDB, $n=1$ and $-9.1 \%$ VPDB, $n=1$, respectively) to $\mathrm{C} 3(-6.6 \pm 1.8 \%$ VPDB, $n=2$, and $-9.5 \pm 1.6 \%$ VPDB, $n=2$, respectively) and D2 $(-0.7 \pm 0.2 \%$ VPDB, $n=20$ and $-8.7 \pm 1.2 \%$ vPDB, $n=20$, respectively) to D3 ( $-4.4 \%$ VPDB, $n=1$ and $-9.6 \%$ VPDB, $n=1$, respectively).

\section{Discussion}

\section{Origin OF DOLOMITES}

\section{Dolomite Petrography and Fluid Inclusions}

The dolomite generations (D1, D2 and D3) of the Watts Bight Formation carbonates exhibit identical petrographic features to those in the equivalent section at Isthmus Bay (Azmy et al., 2009; Conliffe et al., 2009). The very finely crystalline (4-50 $\mu \mathrm{m}$, Fig. 3b), and dull CL response of remnants of D1 likely suggests an early-stage replacement of marine lime muds under near-surface conditions (low temperature) in shallow 
Table 1. Summary of the microthermometric fluid-inclusion data of D2 from the Watts Bight Formation in the investigated interval of Core 12 P/1-12.

\begin{tabular}{|c|c|c|c|c|c|c|c|c|}
\hline $\begin{array}{l}\text { Sample } \\
\text { id\# }\end{array}$ & $\begin{array}{c}\text { Host } \\
\text { Mineral }\end{array}$ & Vapour\% & $\begin{array}{c}\text { Tm-first } \\
\left({ }^{\circ} \mathrm{C}\right)\end{array}$ & $\begin{array}{c}\text { Tm-hydrohalite } \\
\left({ }^{\circ} \mathrm{C}\right)\end{array}$ & $\begin{array}{c}\mathrm{Tm}-\mathrm{H}_{2} \mathrm{O} \\
\left({ }^{\circ} \mathrm{C}\right)\end{array}$ & $\begin{array}{l}\text { Freezing Point } \\
\text { Depression }\end{array}$ & $\begin{array}{l}\text { Eq. wt\% } \mathrm{NaCl} \\
\text { (Bodnar, 2003) }\end{array}$ & $\operatorname{Th}\left({ }^{\circ} \mathrm{C}\right)$ \\
\hline P216 & D2 & 5 & -53.2 & & -21.2 & 21.2 & 23.2 & 137.0 \\
\hline P216 & D2 & 5 & & & & & & 136.0 \\
\hline P216 & D2 & 5 & & & -23.0 & 23.0 & 24.3 & 137.0 \\
\hline P216 & D2 & 5 & -53.2 & & -23.0 & 23.0 & 24.3 & 139.0 \\
\hline P216 & D2 & 5 & & & -21.0 & 21.0 & 23.0 & 146.0 \\
\hline P216 & D2 & 5 & & & -21.2 & 21.2 & 23.2 & 143.0 \\
\hline P216 & D2 & 10 & -54.1 & -34.6 & -20.9 & 20.9 & 23.0 & 179.0 \\
\hline P216 & D2 & 5 & & & & & & 134.0 \\
\hline P216 & D2 & 5 & & & -21.2 & 21.2 & 23.2 & 137.0 \\
\hline P216 & D2 & 5 & & & -21.2 & 21.2 & 23.2 & 144.0 \\
\hline P216 & D2 & 5 & & & & & & 157.0 \\
\hline P216 & D2 & 5 & & & -19.6 & 19.6 & 22.1 & 157.0 \\
\hline P216 & D2 & 5 & & & & & & 141.0 \\
\hline P216 & D2 & 5 & & & & & & 141.0 \\
\hline P216 & D2 & 5 & & & & & & 139.0 \\
\hline P200C & D2 & 3 & & & & & & 102.0 \\
\hline P200C & D2 & 3 & & & & & & 102.0 \\
\hline P200C & D2 & 3 & & & & & & 96.0 \\
\hline P200C & D2 & 3 & & & & & & 96.4 \\
\hline P200C & D2 & 3 & & & -20.8 & 20.8 & 22.9 & 96.0 \\
\hline P200C & D2 & 3 & & & & & & 96.0 \\
\hline P200C & D2 & 3 & & & -18.4 & 18.4 & 21.3 & 98.0 \\
\hline P200C & D2 & 3 & & & -18.4 & 18.4 & 21.3 & 91.0 \\
\hline P200C & D2 & 3 & & & & & & 89.0 \\
\hline P200C & D2 & 3 & -51.9 & & -19.5 & 19.5 & 22.0 & 101.0 \\
\hline P217 & D2 & 5 & & & & & & 100.2 \\
\hline P217 & D2 & 5 & & & -24.3 & 24.3 & 25.1 & 109.0 \\
\hline P217 & D2 & 5 & & & & & & 107.0 \\
\hline P217 & D2 & 5 & & & -23.0 & 23.0 & 24.3 & 107.0 \\
\hline P217 & D2 & 5 & & & & & & 105.0 \\
\hline P217 & D2 & 5 & & & & & & 121.0 \\
\hline P217 & D2 & 5 & & & -21.4 & 21.4 & 23.3 & 125.7 \\
\hline P217 & D2 & 5 & & & & & & 125.7 \\
\hline P217 & D2 & 5 & -50.0 & & -22.0 & 22.0 & 23.7 & 124.0 \\
\hline P217 & D2 & 5 & -49.7 & & -22.0 & 22.0 & 23.7 & 137.0 \\
\hline P217 & D2 & 5 & & & -21.2 & 21.2 & 23.2 & 119.0 \\
\hline P217 & D2 & 5 & & & -22.0 & 22.0 & 23.7 & 112.0 \\
\hline P217 & D2 & 5 & & & & & & 106.4 \\
\hline P217 & D2 & 5 & & & & & & 106.4 \\
\hline P217 & D2 & 3 & & & -20.0 & 20.0 & 22.4 & 145.0 \\
\hline P217 & D2 & 3 & & & -20.0 & 20.0 & 22.4 & 116.0 \\
\hline P217 & D2 & 3 & & & & & & 116.0 \\
\hline P217 & D2 & 3 & & & -20.7 & 20.7 & 22.8 & 112.9 \\
\hline P217 & D2 & 3 & & & & & & 116.0 \\
\hline P217 & D2 & 5 & & & -22.2 & 22.2 & 23.8 & 137.0 \\
\hline P217 & D2 & 5 & & & & & & 148.8 \\
\hline P217 & D2 & 5 & & & -23.0 & 23.0 & 24.3 & 148.8 \\
\hline P217 & D2 & 5 & & & -23.0 & 23.0 & 24.3 & 139.0 \\
\hline P217 & D2 & 5 & & & -22.0 & 22.0 & 23.7 & 139.0 \\
\hline P221 & D2 & 5 & & & -22.7 & 22.7 & 24.1 & 134.0 \\
\hline P221 & D2 & 5 & & & & & & 133.0 \\
\hline P221 & D2 & 5 & & & & & & 133.0 \\
\hline P221 & D2 & 5 & & & -20.1 & 20.1 & 22.4 & 137.0 \\
\hline P221 & D2 & 5 & & & -22.0 & 22.0 & 23.7 & 143.0 \\
\hline P221 & D2 & 5 & & & -20.7 & 20.7 & 22.8 & 136.0 \\
\hline P221 & D2 & 3 & & & & & & 138.3 \\
\hline P221 & D2 & 3 & & & -20.4 & 20.4 & 22.6 & 131.0 \\
\hline P221 & D2 & 3 & & & & & & 137.2 \\
\hline P221 & D2 & 3 & & & & & & 137.2 \\
\hline P221 & D2 & 3 & & & & & & 140.0 \\
\hline P221 & D2 & 3 & & & & & & 140.0 \\
\hline
\end{tabular}




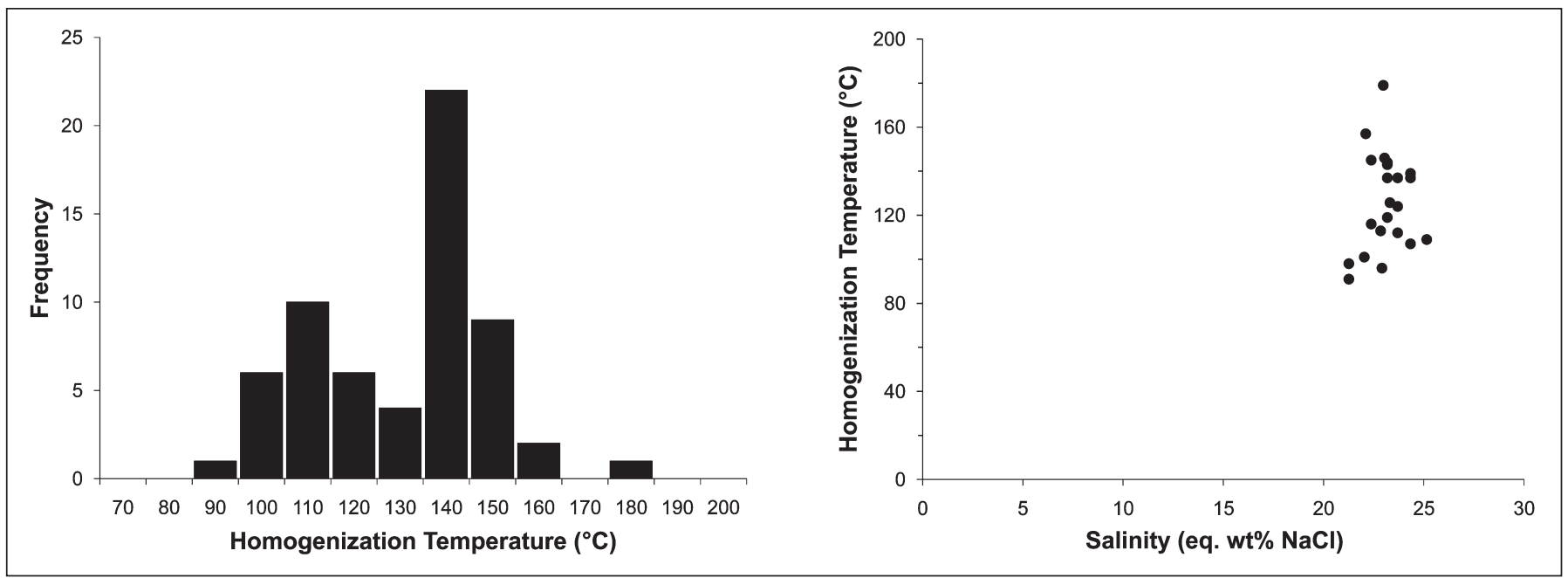

Fig. 4. Plots of the microthermometric data from primary two-phase fluid inclusions trapped in D2 of the Watts Bight Formation on the Northern Peninsula showing (a) histograms of homogenization temperatures and (b) a correlation scatter diagram of estimated salinity (Bodnar, 2003) vs. homogenization temperature.

Table 2. $\mathrm{CaCO}_{3}, \mathrm{MgCO}_{3}, \mathrm{Mn}, \mathrm{Sr}, \mathrm{Fe}, \delta^{18} \mathrm{O}$ and $\delta^{13} \mathrm{C}$ statistics for Watts Bight Formation carbonates in the investigated core section on the Northern Peninsula (current study) and the Isthmus Bay equivalent section on the Port au Port Peninsula (Conliffe et al., 2009).

\begin{tabular}{|c|c|c|c|c|c|c|c|c|}
\hline Phase & & $\mathrm{CaCO}_{3} \%$ & $\mathrm{MgCO}_{3} \%$ & $\mathrm{Sr}(\mathrm{ppm})$ & Mn (ppm) & $\mathrm{Fe}(\mathrm{ppm})$ & $\delta^{13} \mathrm{C} \%$ VPDB & $\delta^{18} \mathrm{O} \% \mathrm{VPDB}$ \\
\hline \multicolumn{9}{|c|}{ Watts Bight Fm (Northern Peninsula) } \\
\hline \multirow[t]{2}{*}{$\mathrm{C} 1$} & $n$ & & & & & & 1 & 1 \\
\hline & average & & & & & & -1.4 & -9.6 \\
\hline \multirow[t]{2}{*}{$\mathrm{C} 3$} & $n$ & 2 & 2 & 2 & 2 & 2 & 2 & 2 \\
\hline & average & $98.4 \pm 1.3$ & $1.6 \pm 1.3$ & $185 \pm 51$ & $387 \pm 139$ & $1291 \pm 28$ & $-6.2 \pm 1.8$ & $-9.5 \pm 1.6$ \\
\hline \multirow[t]{2}{*}{ D2 } & $n$ & 20 & 20 & 20 & 20 & 20 & 43 & 43 \\
\hline & average & $56.5 \pm 6.7$ & $43.5 \pm 6.7$ & $68 \pm 30$ & $97 \pm 33$ & $1548 \pm 1552$ & $-0.7 \pm 0.2$ & $-8.7 \pm 1.2$ \\
\hline \multirow[t]{2}{*}{ D3 } & $n$ & 1 & 1 & 1 & 1 & 1 & 1 & 1 \\
\hline & & 60.5 & 39.5 & 61 & 220 & 1396 & -4.4 & -9.6 \\
\hline \multicolumn{9}{|c|}{ Watts Bight Fm (Isthumus Bay) } \\
\hline \multirow[t]{2}{*}{ C1 } & $n$ & 7 & 7 & 7 & 7 & 7 & 12 & 12 \\
\hline & average & $98.5 \pm 0.8$ & $1.5 \pm 0.8$ & $320 \pm 50$ & $168 \pm 82$ & $64 \pm 23$ & $-1.3 \pm 0.6$ & $-7.8 \pm 0.3$ \\
\hline \multirow[t]{2}{*}{$\mathrm{C} 3$} & $n$ & 2 & 2 & 2 & 2 & 2 & 2 & 2 \\
\hline & average & $98.9 \pm 0.1$ & $1.1 \pm 0.1$ & $137 \pm 51$ & $29 \pm 6$ & $31 \pm 14$ & $-3.3 \pm 2.5$ & $-7.6 \pm 0.4$ \\
\hline \multirow[t]{2}{*}{ D2 } & $n$ & 20 & 20 & 20 & 20 & 20 & 29 & 29 \\
\hline & average & $59.3 \pm 3.7$ & $40.7 \pm 3.7$ & $97 \pm 63$ & $73 \pm 38$ & $639 \pm 268$ & $-1.4 \pm 0.3$ & $-8.6 \pm 1.9$ \\
\hline \multirow[t]{2}{*}{ D3 } & $n$ & 2 & 2 & 2 & 2 & 2 & 4 & 4 \\
\hline & average & $62.1 \pm 5.8$ & $37.9 \pm 5.8$ & $122 \pm 46$ & $139 \pm 113$ & $617 \pm 367$ & $-1.3 \pm 0.5$ & $-7.5 \pm 1.9$ \\
\hline
\end{tabular}


burial settings, which is similar to the implied origin of D1 in the Isthmus Bay section (Azmy et al., 2009, Conliffe et al., 2009).

The D2 crystals show no fabric retention and are larger and crosscut by an early phase of solution seams (Fig. 3a-d). This may suggest a later stage of replacement, which likely started at deeper burial settings of relatively higher temperatures compared with D1 (cf. Choquette and James, 1987; Warren, 2000). They have cloudy cores and clear rims (Fig. 3a-c) and exhibit sweeping extinction and distinctive zoned CL images (Fig. 3d), suggesting a change in the redox conditions and chemistry of the parent dolomitizing fluid during the course of crystallization (e.g. Rameil, 2008; Kirmac1, 2008). The same features have been also documented for the D2 phase of the Isthmus Bay section (Azmy et al., 2009; Conliffe et al., 2009), although the D2 crystals of the Isthmus Bay section were relatively smaller compared to those in the investigated core and do not exhibit sweeping extinction. The bigger crystal size and sweeping extinction reflect relatively deeper burial conditions. This is consistent with the higher $T_{h}$ values measured, particularly from the coarser D2 crystals (Table 1). The bimodal distribution of $T_{h}$ (Fig. 4a) and invariable salinity (Fig. 4b) suggests that the deposition of D2 likely occurred from fluids of almost the same salinity but during two major pulses at different temperatures.

The petrographic features of the D2 crystals, particularly those with intercrystalline pores, are similar to those documented for the Type 3 dolomite of the Ordovician Ellenberger Group carbonates in western Texas (Lee and Friedman, 1978) and also the matrix dolomite of the Middle Devonian Slave Point Formation in British Columbia, Canada (Lonnee and Machel, 2006). However, microthermometric investigations indicate that the average $T_{h}$ values of the Ellenberger Type 3 dolomites (approximately 150 to $320^{\circ} \mathrm{C}$ ) are higher than those of D2 in Watts Bight, although the estimated salinity for the Slave Point matrix dolomite (23 to $24 \%$ ) is comparable. The range of $T_{h}$ values of the cores of the Slave Point matrix dolomite crystals (approximately 140 to $150^{\circ} \mathrm{C}$ ) is comparable to those of the Watts Bight Formation although the $T_{h}$ values of their outer rims are slightly higher (approximately 180 to $200^{\circ} \mathrm{C}$, Lonnee and Machel, 2006).

\section{Major and trace elements}

The $\mathrm{Mn}$ and Fe contents of dolomites may reflect the redox conditions of deposition and the nature of burial settings. The higher Mn and Fe content of D2 in the investigated core $(97 \pm 33$ ppm, $n=20$ and $1548 \pm 1552$ ppm, $n=20$, respectively; Table 2) compared with the Isthmus Bay section $(73 \pm 38$ ppm, $n=20$ and $639 \pm 268 \mathrm{ppm}, n=20$, respectively; Table 2) may suggest deposition under relatively more reducing conditions, which is also consistent with the zoned CL images (e.g. Al-Aasm, 2003; Lavoie and Morin, 2004; Lonnee and Machel, 2006; Davies and Smith, 2006; Azmy et al., 2009; Conliffe et al., 2009; Conliffe et al., 2010; Lavoie et al., 2010). This also agrees with the high values of measured $\mathrm{T}_{\mathrm{h}}$ 's and estimated salinities (up to $157^{\circ} \mathrm{C}$ and 24.3 eq. wt $\% \mathrm{NaCl}$, Table 1 ), which support precipitation from hotter saline brines.

\section{Oxygen and Carbon Isotopes}

The $\delta^{13} \mathrm{C}$ and $\delta^{18} \mathrm{O}$ values of the Watts Bight Formation carbonates in the core decrease from $\mathrm{C} 1$ to $\mathrm{C} 3$, which may reflect the increase in burial diagenesis with depth. However, the $\delta^{13} \mathrm{C}$ values of the lime mudstones (C1) and D2 of Watts Bight Formation in the Northern Peninsula (Fig. 5) exhibit considerable overlap. This may suggest that the lime mudstone was the precursor of those dolomites since dolomitizing waters have generally low dissolved $\mathrm{CO}_{2}$ (low $\mathrm{pCO}_{2}$ ) (Land, 1992), a situation similar to that documented for the equivalent section exposed at Isthmus Bay on the Port au Port Peninsula (Azmy et al., 2009; Conliffe et al., 2009).

Regardless, the depositional facies, the general enrichment in the $\delta^{13} \mathrm{C}$ values of the Northern Peninsula dolomites compared with their Isthmus Bay equivalents may reflect the signature of their precursor marine carbonates. It may also be attributable to the influence of a relatively shallower depositional setting, possibly restricted by a local barrier, with higher organic primary productivity (e.g. Immenhauser et al., 2008). Also, the narrow range of $\delta^{13} \mathrm{C}$ variations in the investigated D2 carbonates of the core section suggests localized circulation of diagenetic fluids with homogenous composition (Conliffe et al., 2009) rather than regional mixing with magmatic fluids (e.g. Lavoie et al., 2010). This has also been suggested for the dolomites at Isthmus Bay (Azmy et al., 2009; Conliffe et al., 2009). It is noteworthy that the mean $\delta^{13} \mathrm{C}$ composition of D2 in the Watts Bight Formation on the Northern Peninsula $(-0.7 \pm 0.2 \%$ VPDB,$n=43)$ is almost identical to that of the micritic carbonates of the equivalent Antiklinalbugt Formation $(-0.6 \pm 0.5 \%$ VPDB,$n=54)$ at Kong Oscar Fjord on Ella $\varnothing$ Island in Northeast Greenland. This may support the paleogeographic model that western Newfoundland and northeast Greenland formed part of the eastern Laurentian margin during the Early Ordovician (cf. Azmy et al., 2010). It may also support the suggestion of limited $\mathrm{pCO}_{2}$ in the dolomitizing fluids and is consistent with the effect of localized diagenetic water circulation under possibly closed or semi-closed conditions.

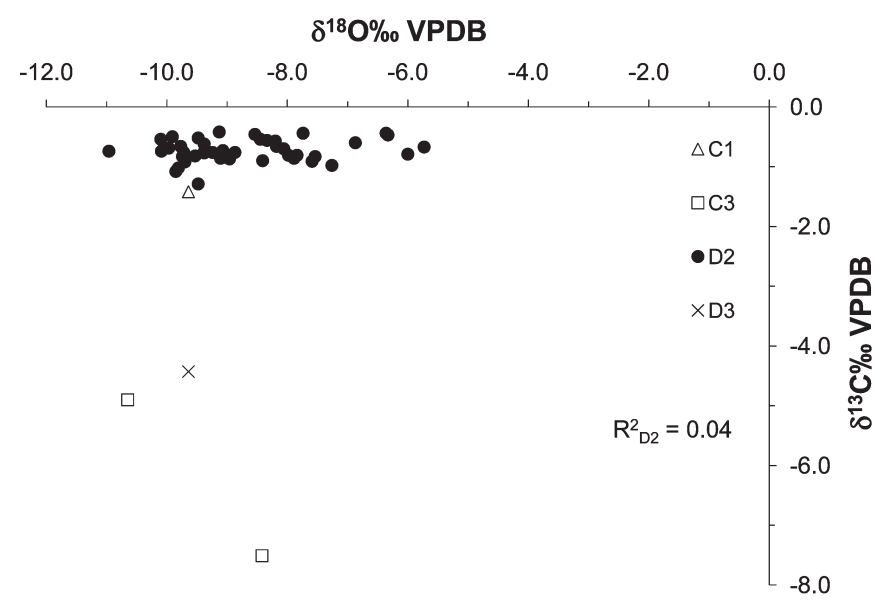

Fig. 5. Scatter diagram of $\delta^{18} \mathrm{O}$ vs $\delta^{13} \mathrm{C}$ for the different Watts Bight Formation carbonate phases in the investigated core section. 
The $T_{h}$ values of the primary two-phase inclusions in D2 reflect deposition from similar burial fluids - salinity is almost invariable - but likely during two major episodes at mean temperatures between $107^{\circ} \mathrm{C}$ and $140^{\circ} \mathrm{C}$ (Fig. 4a). Assuming that $T_{h}$ is an estimate of the minimum entrapment temperatures and given that $\mathrm{O}$-isotopic compositions of $\mathrm{D} 2$ are from -11 to $-5.7 \%$ VPDB (Appendix 1 and Table 2), the estimated $\delta^{18} \mathrm{O}$ compositions of the dolomitizing fluids might have ranged between approximately +4 and $+6 \%$ VSMOW $\left(10^{3} \ln \mathrm{a}=3.2\right.$ * $10^{6} \mathrm{~T}^{-2}-3.3$, Land, 1983). High-temperature basinal brines of deep burial settings are commonly known to be enriched in ${ }^{18} \mathrm{O}$ and are highly saline regardless of age or location (e.g. Goldstein and Reynolds, 1994; Azmy et al., 2001; Lonnee and Machel, 2006; Conliffe et al., 2009, 2010). This also is consistent with the estimated high salinities of D2 (Fig. 4b and Table 1). The similarity between the estimated salinity for the investigated section on Northern Peninsula $(23.2 \pm 0.9 \%, n=31)$ and its Isthmus Bay counterpart $(17.5 \pm 4.5 \%, n=31)$ suggests that D2 was deposited in both locations by similar, if not the same, fluids (Conliffe et al., 2010), which were circulated to relatively deeper settings and became hotter.

\section{VARIATIONS IN VERTICAL AND LATERAL Distribution of Porosity}

Porosity $(\varnothing)$ is a key parameter in reservoir characterization, making the development of secondary pores a significant issue in the evolution of carbonate hydrocarbon reservoirs. Petrographic study of lower St. George Group carbonates on the Northern Peninsula indicates that secondary porosity is the dominant type and mainly is associated with dolomitization (e.g. Dravis, 1992; Esteban and Taberner, 2003; Wierzbicki et al., 2006; Azmy et al, 2009; Conliffe et al., 2009). Visual estimates suggest that porosity varies between $<1$ and $10 \%$. Pores are mainly intercrystalline (apparent long axes of pores from 70 to $350 \mu \mathrm{m}$ ), similar to those in the equivalent Isthmus Bay section but slightly bigger (Fig. 3c). In the Watts Bight Formation on the Northern Peninsula, D2 in the porous intervals (visual estimate $\varnothing=4$ to $10 \%$ ) generally has higher $\mathrm{CaCO}_{3}$ contents $(62.1 \pm 0.9 \%, n=5)$ than the non-porous D2 (54.6 $\pm 6.7 \%, n=15)$ (Appendix 1). This may suggest that D2 originated by direct dolomitization of precursor calcite rather than by recrystallization of pre-existing dolomicrite. The difference in molar crystal volume between the dolomite and its precursor calcite and dolomitization under possibly closed to semi-closed conditions likely played a major role in the development of the D2-associated porosity of the few porous layers (Appendix 1, Azmy et al., 2008, 2009; Conliffe et al., 2009), despite the pervasive dolomitization that affected most of the sequence. If dolomitization of porous layers was under completely open system conditions, the resulting pores would have been occluded with dolomite cements but this is not the case. Therefore, the non-porous D2 probably developed by recrystallization of the precursor (D1) dolomicrite (e.g. Azmy et al., 2009). However, the limited nature of the available data suggests that conclusions of this pilot study should be taken with caution until other correlative sections from the same area are investigated.

The petrographic features of the $\mathrm{D} 2$ crystals, particularly the porous phase, are similar to those documented for the Type 3 dolomite of the Ordovician Ellenberger Group carbonates (oil reservoir) in western Texas (Lee and Friedman, 1978) and also the matrix dolomite of the Middle Devonian Slave Point Formation (gas reservoir) in British Columbia, Canada (Lonnee and Machel, 2006). The occurrence of the organic-rich shale of the Green Point Formation in the region, and structural traps involving the St. George Group carbonates, suggest the Watts Bight Formation is a potential reservoir.

Dissolution vugs (up to $5 \mathrm{~mm}$ wide) also occur in the dolostones and are, in places, occluded by the late non-ferroan D3 (late saddle dolomite) and C3 (latest pore-filling calcite) as at the Isthmus Bay section. The depleted $\delta^{18} \mathrm{O}$ signals of $\mathrm{C} 3 \mathrm{com}$ pared to those of D3 (Table 2, Appendix 1), suggest that $\mathrm{C} 3$ was likely formed in similar deep burial settings of high temperature (e.g. Azmy et al., 2009; Conliffe et al., 2009).

The porous Watts Bight D2 in the core $(\varnothing=4-10 \%)$ occurs in 2 layers. One is approximately $2 \mathrm{~m}$ thick, approximately 10 $\mathrm{m}$ from the base of the formation and the other is approximately $3 \mathrm{~m}$ thick, some $20 \mathrm{~m}$ from the base (Fig. 2, Appendix 1). Similarly, porosity was associated with D2 in the equivalent section at Isthmus Bay, but there the porous layers $(\varnothing=4-7 \%)$ are one that is approximately $6 \mathrm{~m}$ thick, approximately $10 \mathrm{~m}$ from the base of the formation, and another that is approximately $2 \mathrm{~m}$ thick, about $48 \mathrm{~m}$ from the base (Conliffe et al., 2009). The unconformable to disconformable upper and lower contacts of the Watts Bight Formation (Knight et al., 2008) suggest that the two sections need to be studied further as to their detailed stratigraphic correlation. The low biostratigraphic resolution (Zhang and Barnes, 2004) makes C-isotope stratigraphy a potential correlation tool (e.g. Azmy and Lavoie, 2009; Azmy et al., 2010) but this depends on the degree of preservation of the retained $\delta^{13} \mathrm{C}$ signatures in those carbonates. The insignificant variations between the $\delta^{13} \mathrm{C}$ and $\mathrm{Mn} / \mathrm{Sr}$ values (Fig. 6) and between $\delta^{18} \mathrm{O}$ and $\delta^{13} \mathrm{C}$ values (Fig. 5) of Watts Bight Formation carbonates on the Northern Peninsula suggest that the $\delta^{13} \mathrm{C}$ values of the investigated rocks are nearprimary, which supports the reliability of the $\mathrm{C}$-isotope profile for chemostratigraphic correlations (e.g. Azmy and Lavoie, 2009; Azmy et al., 2010). The $\delta^{13} \mathrm{C}$ profiles show negative shifts of approximately 1 to $1.3 \%$ in the middle of both sections and at the top boundary (Watts Bight/Boat Harbour disconformity, Knight et al., 2008) of the Northern Peninsula section (Fig. 2). The shifts may reflect sea-level fluctuations (Azmy and Lavoie, 2009; Azmy et al., 2010) although no sedimentary hiatuses have yet been documented correlating with the middle $\delta^{13} \mathrm{C}$ shift. The absence of the upper isotopic shift at Isthmus Bay could be related to the resolution of sampling at the top part of the section or possibly an unidentified sedimentary hiatus (cf. Azmy and Lavoie, 2009, their appendix 1).

The drop in sea level might have probably brought oxygenrich shallow seawater into contact with buried organic matter and (or) induced migration within the shallow buried sediments 


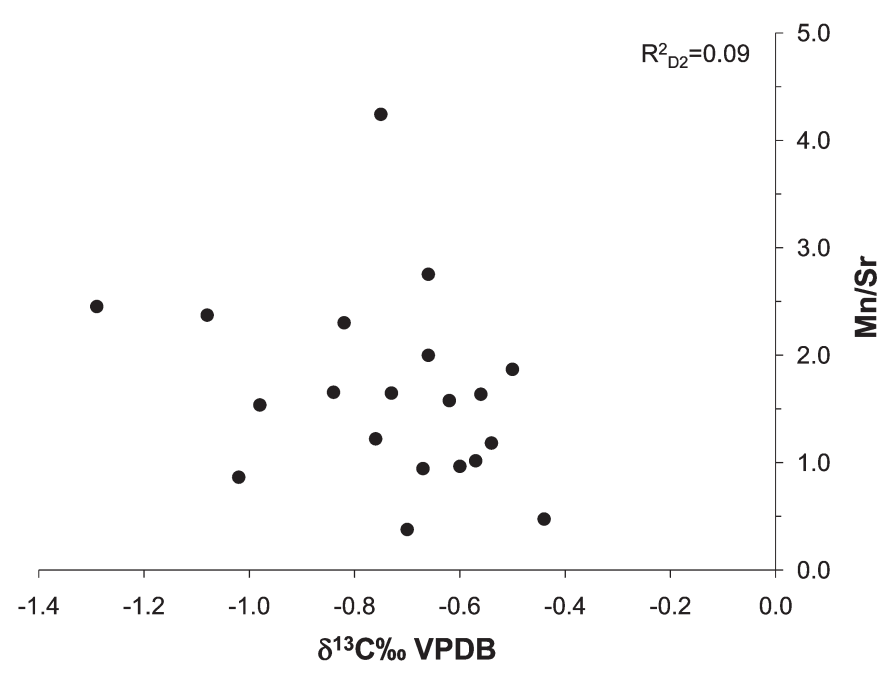

Fig. 6. Scatter diagram of $\delta^{13} \mathrm{C}$ vs $\mathrm{Mn} / \mathrm{Sr}$ for the Watts Bight Formation D2 phase in the investigated core section showing insignificant correlation. Details in text.

of an unconformity-related lowstand lens of oxygenated water that oxidized organic matter to release ${ }^{12} \mathrm{C}$-rich bicarbonate ions (cf. Holmden et al. 1998; Immenhauser et al. 2008). Therefore negative shifts are likely caused by local drops in sea-level and brief exposure to meteoric waters, possibly developing a preliminary diagenetic pore system that contributed to enhanced movement of the diagenetic fluids and dolomitization (e.g. Azmy et al., 2009). The suggested closed to semiclosed system conditions and restricted sources of dolomitizing fluids likely led to preservation of the secondary porosity. The rough correlation of the $\mathrm{C}$-isotope profiles may suggest that both sections cover approximately the same time interval. The porous zones in both sections (Fig. 2) are possibly associated with sea-level changes, indicated by the negative $\delta^{13} \mathrm{C}$ shifts (Azmy et al., 2008, 2009; Conliffe et al., 2009). The negative $\delta^{13} \mathrm{C}$ shifts on the $\mathrm{C}$-isotope profile may thus, in some cases, be a potential geochemical proxy for tracing and predicting the stratigraphic levels of porous zones. However, this is not always the case and has to be applied cautiously because other $\delta^{13} \mathrm{C}$ shifts on the St. George C-isotope profile (e.g. the shift associated with the Boat Harbour lower disconformity) are not associated with porosity (Azmy et al., 2009; Azmy and Lavoie, 2009). Further studies on equivalent sections in the surrounding area should shed more light on the issue.

\section{Conclusions}

Petrographic examination of the Watts Bight Formation carbonates from Core 12P/1-12 on the Northern Peninsula of western Newfoundland reveals the presence of three phases of dolomite. From the oldest to the youngest, these are: dolomicrite (D1); eu- to subhedral, zoned saddle dolomite (D2); and anhedral, pore-filling dolomite (D3). D1 and D3 are rare. The formation consists almost entirely of D2 dolomite, except for an approximately $2 \mathrm{~m}$-thick lime mudstone bed near the top.
Intercrystalline porosity $(\varnothing=4-10 \%)$ is the dominant type and associated with D2 in two horizons of the formation.

Trace element and stable isotope geochemistry of the dolomites and microthermometric measurements on trapped, primary two-phase fluid inclusions suggest that formation of D2 started under reducing conditions, at greater depth than D1, and from hotter solutions $\left(107-140^{\circ} \mathrm{C}\right)$ than those that formed D2 in correlative strata at Isthmus Bay, Port au Port Peninsula.

The apparent correlation of the stratigraphic levels of porous layers in the Watts Bight Formation on Northern Peninsula with their equivalents of the Isthmus Bay section - a separation of approximately $300 \mathrm{~km}$ - suggests that these zones could be more or less continuous across western Newfoundland, although not necessary at the exact stratigraphic level. The porous zones may be related to sea-level fluctuations, because they are present immediately beneath disconformity surfaces and beds recording negative $\delta^{13} \mathrm{C}$ shifts. That said, the complicated tectonic setting and intense faulting that followed dolomitization, preclude precise regional correlation of the porous zones. While the zones appear roughly correlative, they may also represent discontinuous, porous geo-bodies. Results from studies on other outcrops or drill holes through Watts Bight Formation in the region will provide more conclusive constraints.

\section{ACKNOWLEDGMENTS}

The authors wish to thank Drs. J. Packard (Associate Editor), L. Smith, and J. Weissenberger for their constructive reviews. Also, efforts of Dr. Rob MacNaughton (Editor-in-Chief) are much appreciated. This project was supported by funding (to Karem Azmy) from Petroleum Research Atlantic Canada (PRAC) and Petroleum Exploration Enhancement Program (PEEP).

\section{REFERENCES}

Al-Aasm, I. 2003. Origin and characterization of hydrothermal dolomite in the Western Canada Sedimentary Basin. Journal of Geochemical Exploration, v. $78-79$, p. $9-15$.

Azmy, K., and Lavoie, D., 2009. High-resolution isotope stratigraphy of the Lower Ordovician St. George Group of western Newfoundland, Canada: implications for global correlation. Canadian Journal of Earth Sciences, v. 46, p. 403-423.

, Knight, I., Lavoie, D. and Chi, G., 2009. Origin of the Boat Harbour dolomites of St. George Group in western Newfoundland, Canada: implications for porosity controls. Bulletin of Canadian Petroleum Geology, v. 57 , p. $81-104$.

, Lavoie, D., Knight, I. and Chi, G. 2008. Dolomitization of the Aguathuna Formation carbonates of Port au Port Peninsula in western Newfoundland, Canada: implications for a hydrocarbon reservoir. Canadian Journal of Earth Sciences, v. 45, p. 795-813.

, Stouge, S., Christiansen, J.L., Harper, D.A.T., Knight, I. and Boyce, D. 2010. Carbon-isotope stratigraphy of the Lower Ordovician succession in Northeast Greenland: implications for correlations with St. George Group in western Newfoundland (Canada) and beyond. Sedimentary Geology, v. 225, p. 67-81.

, Veizer, J., Misi, A., De Olivia, T., Sanches, A.L. and Dardenne, M. 2001. Isotope stratigraphy of the Neoproterozoic carbonate of Vazante 
Formation Saõ Francisco Basin, Brazil. Precambrian Research, v. 112, p. 303-329.

Baker, D. and Knight, I. 1993. The Catoche dolomite project, Anticosti Basin, eastern Canada: CERR Report, Memorial University of Newfoundland, St. John's, Newfoundland, $174 \mathrm{p}$.

Bodnar, R.J. 2003. Interpretation of data from aqueous-electrolyte fluid inclusions. In: I. Samson, A. Anderson and D. Marshal (eds.). Fluid Inclusions: Analyses and Interpretation. Mineralogical Association of Canada. Short Course Series, 32, p. 81-100.

Budd, D.A. 1997. Cenozoic dolomites of carbonate islands: their attributes and origin. Earth-Science Reviews, v. 42, p. 1-47.

Cawood, P.A., McCausland, P.J.A. and Dunning, G.R. 2001. Opening Iapetus: Constraints from Laurentian margin in Newfoundland. Geological Society of America Bulletin, v. 113, p. 443-453.

Choquette, P.W. and James, N.P. 1987. Diagenesis in Limestones-3. The deep burial environment. Geoscience Canada, v. 14, p. 3-36.

Coleman, M.L., Walsh, J.N. and Benmore, R.A., 1989. Determination of both chemical and stable isotope composition in milligram-size carbonate samples. Sedimentary Geology, v. 65, p. 233-238.

Conliffe, J., Azmy, K., Gleeson, S.A. and Lavoie, D. 2010. Fluids associated with hydrothermal dolomitization in St. George Group, western Newfoundland, Canada. Geofluids (in press).

Knight, I. and Lavoie, D. 2009. Dolomitization in the Lower Ordovician Watts Bight Formation of the St. Georges Group, western Newfoundland. Canadian Journal of Earth Sciences, v. 46, p. 247-261.

Cooper, M., Weissenberger, J., Knight, I., Hostad, D., Gillespie, D., Williams, H., Burden, B., Porter-Chaudhry, J., Rae, D. and Clark, E. 2001. Basin evolution in western Newfoundland: new insights from hydrocarbon exploration. American Association of Petroleum Geologists Bulletin, v. 85, p. 393-418.

Davies, G.R. and Smith, L.B. 2006. Structurally controlled hydrothermal dolomite reservoir: an overview. The American Association of Petroleum Geologists Bulletin, v. 90, p. 1641-1690.

Dravis, J.J. 1992. Burial dissolution in limestones and dolomites - criteria for recognition and discussion of controls: a case study approach (part 1): Upper Jurassic Haynesville limestones, east Texas; part 2: Devonian Upper Elk Point dolomites, western Canada. American Association of Petroleum Geologists-Canadian Society of Petroleum Geologists Short Course on Subsurface Dissolution Porosity in Carbonates, Calgary, Canada, 171 p.

Esteban, M. and Taberner, C. 2003. Secondary porosity development during late burial in carbonate reservoirs as a result of mixing and/or cooling of brines. Journal of Geochemical Exploration, v. 78-79, p. 355-359.

Fowler, M.G., Hamblin, A.P., Hawkins, D., Stasiuk, L.D. and Knight, I. 1995. Petroleum geochemistry and hydrocarbon potential of Cambrian and Ordovician rocks of western Newfoundland. Bulletin of Canadian Petroleum Geology, v. 43, p. 187-213.

Goldstein, R.H. and Reynolds, T.J. 1994. Systematics of fluid inclusions in diagenetic minerals. Short course 31, SEPM (Society for Sedimentary Geology), 199 p.

Greene, M., 2008. Multiple generations of dolomitization in the Catoche Formation, Port au Choix, Newfoundland. MSc Thesis, Memorial University of Newfoundland, $146 \mathrm{p}$.

Haywick, D.W. 1984. Dolomite within the St. George Group (Lower Ordovician), western Newfoundland. Unpublished M.Sc. thesis, Memorial University of Newfoundland, St. John's Newfoundland. 281 p.

Holmden, C., Creaser, R.A., Muehlenbachs, K., Leslie, S.A. and Bergström, S.M. 1998. Isotopic evidence for geochemical decoupling between ancient epeiric seas and bordering oceans: implications for secular curves. Geology, v. 26, p. 567-570.

Immenhauser, I., Holmden, C. and Patterson, W.P. 2008. Interpreting the carbon-isotope record of ancient shallow epiric seas: lessons from the recent. Geological Association of Canada, Special Paper 48, p. 137-74.

James, N.P., Stevens, R.K., Barnes, C.R. and Knight, I. 1989. Evolution of a Lower Paleozoic continental-margin carbonate platform, northern Canadian Appalachians. In: P. D. Crevello, J. L. Wilson, J. F. Sarg and J. F. Read (eds.). Controls on Carbonate Platform and Basin Development,
Society of Economic Paleontologists and Mineralogists Special Publication, v. 44, p. 123-146.

Kırmac1, M.Z. 2008. Dolomitization of the late Cretaceous-Paleocene platform carbonates, Gölköy (Ordu), eastern Pontides, NE Turkey. Sedimentary Geology, v. 20, p. 289-306.

Knight, I. 1991. Geology of Cambro-Ordovician rocks in the Port Saunders (NTS 12I/11), Castors River (NTS12I/15), St. John Island (NTS 12I/14) and Torrent River (NTS 121/10) map areas. In: R. F. Blackwood, C. P. G. Pereira and D. G. Walsh (eds.). Newfoundland Department of Mines and Energy, Mineral Development Division, Report 91-4, 138 p.

1996. Stratigraphic logs of carbonate rocks of western Newfoundland. Based on mineral exploration drill hole logs. Newfoundland Department of Mines and Energy Resource Division open file release 1996-PRD-1, 91 p. and James, N. P. 1987. Stratigraphy of the St. George Group (Lower Ordovician), western Newfoundland: the interaction between eustasy and tectonics. Canadian Journal of Earth Sciences, v. 24, p. 1927-1952. and Lane, T. E. 1991. The Ordovician St. George Unconformity, northern Appalcachians: the relationship of plate convergence at the St. Lawrence Promontory to the Sauk/Tippecanoe sequence boundary. Geological Society of America Bulletin, v. 103, p. 1200-1225.

, Azmy, K., Boyce, D. and Lavoie, D. 2008. Tremadocian carbonates of the lower St. George Group, Port au Port Peninsula, western Newfoundland: Lithostratigraphic setting of diagenetic, isotopic, and geochemistry studies. Current Research. Newfoundland and Labrador Department of Natural Resources Geological Survey. Report 08-1, p. 1-43. , Greene, M. and Lavoie, D. 2007. Lithostratigraphic setting of diagenetic, isotopic, and geochemistry studies of Ibexian and Whiterockian carbonates of the St. George and Table Head groups in western Newfoundland. Current Research Newfoundland and Labrador Department of Natural Resources Geological Survey. Report 07-1, p. 55-84.

Land, L.S. 1983. The application of stable isotopes to studies of the origin of dolomite and to problems of diagenesis of clastic sediments, In: M. A. Arthur, T. F. Anderson, I. R. Kaplan, J. Veizer and L.S. Land (eds.). Stable Isotopes in Sedimentary Geology. SEPM Short Course Notes 10, p. 4-1- 4-22.

1992. The dolomite problem: stable and radiogenic isotope clues, In: N. Clauer and S. Chaudhuri (eds.). Isotopic Signature of Sedimentary Records. Lecture Notes in Earth Science, v. 43, p. 49-68.

Lane, T.E. 1990. Dolomitization, brecciation and zinc mineralization and their paragenetic, stratigraphic and structural relationships in the upper St. George Group (Ordovician) at Daniel's Harbour, western Newfoundland. Unpublished $\mathrm{PhD}$ Thesis, Memorial University of Newfoundland, $496 \mathrm{p}$.

Lavoie, D. and Chi, G. 2006. Hydrothermal dolomitization in the Lower Silurian La Vieille Formation in northern New Brunswick: geological context and significance for hydrocarbon exploration. Bulletin of Canadian Petroleum Geology, v. 54, p. 380-395.

and Morin, C. 2004. Hydrothermal dolomitization in the Lower Silurian Sayabec Formation in northern Gaspé - Matapédia (Québec): constraints on timing of porosity and regional significance of hydrocarbon reservoirs. Bulletin of Canadian Petroleum Geology, v. 52 (3), p. 256-269.

Chi, G., Brennan-Alpert, P. and Betrand, R. 2005. Hydrothermal dolomitization in the Lower Ordovician Romaine Formation of the Anticosti Basin: significance for hydrocarbon exploration. Bulletin of Canadian Petroleum Geology, v. 53, p. 454-471.

, Urbatsch, M. and Davis, W.J. 2010. Massive dolomitization of a pinnacle reef in the Lower Devonian West Point Formation (Gaspé Peninsula, Quebec): an extreme case of hydrothermal dolomitization through fault-focused circulation of magmatic fluids. American Association of Petroleum Geologists Bulletin, v. 94, p. 513-531.

Lee, Y.I., Friedman, G.M. 1978. Deep-burial dolomitization in the Ordovician Ellenberger Group carbonates, west Texas and southeastern New Mexico. Journal of Sedimentary Petrology, v. 57, p. 544-577.

Lonnee, J. and Machel, H.G. 2006. Pervasive dolomitization with subsequent hydrothermal alteration in the Clarke Lake gas field, Middle Devonian Slave Point Formation, British Columbia, Canada. American Association of Petroleum Geologists Bulletin, v. 90, p. 1739-1761. 
Machel, H.G. and Mountjoy, E.W. 1986. Chemistry and environments of dolomitization - a reappraisal. Earth-Science Reviews, v. 23, p. 175-202. and 1990. Coastal mixing zone dolomite, forward modelling, and massive dolomitization of platform-margin carbonate-Discussion. Journal of Sedimentary Petrology, v. 60, p. 1008-1012.

Pratt, B.R. and James, N. P. 1986. The tidal flat island model for peritidal shallow-upward sequences; St. George Group, western Newfoundland. Sedimentology, v. 33, p. 313-344.

Rameil, N. 2008. Early diagenetic dolomitization and dedolomitization of Late Jurassic and earliest Cretaceous platform carbonates: a case study from the Jura Mountains (NW Switzerland, E France). Sedimentary Geology, v. 212, p. $70-85$.

Sibley, D.F. 1982. Origin of common dolomite fabrics: clues from the Pliocene. Journal of Sedimentary Petrology, v. 52, p. 1087-1100.

Shepherd, T.J., Rankin, A.H. and Alderton, D.H.M. 1985. A Practical Guide to Fluid Inclusions. Blackie, London.

Smith, L.B. 2006. Origin and reservoir characteristics of Upper Ordovician Trenton-Black River hydrothermal dolomite reservoirs in New York. Bulletin of the American Association of Petroleum Geologists, v. 90, p. 1691-1718.

Smith, P.M., Rasmussen, J.A. 2008. Cambrian-Silurian development of the Laurentian margin of the Iapetus Ocean in Greenland and related areas. In: A.K. Higgins, J. Gilotti and P.M. Smith (eds.). The Greenland Caledonides: Evolution of the Northeast Margin of Laurentia. Geological Society of America Memoir, 202, p. 137-168.
Stockmal, G.S., Slingsby, A. and Waldron, J.W.F. 1998. Deformation styles at the Appalachian structural front, western Newfoundland: implications of new industry seismic reflection data. Canadian Journal of Earth Sciences, v. 35 , p. $1288-1306$.

Warren, J. 2000. Dolomite: occurrence, evolution, and economically important associations. Earth- Science Reviews, v. 52, p. 1-81.

Wierzbicki, R., Dravis, J. J., Al-Aasm, I. and Harland, N. 2006. Burial dolomitization and dissolution of Upper Jurassic Abenaki platform carbonates, Deep Panuke reservoir, Nova Scotia, Canada. American Association of Petroleum Geologists Bulletin, v. 90, p. 1843-1861.

Wilson, J.L., Medlock, P.L., Fritz, R.D., Canter, K.L. and Geesaman, R G. 1992. A review of Cambro-Ordovician breccias in North America. In: M. P. Candelaria and C. L. Reed (eds.). Paleokarst, karst-related diagenesis and reservoir development. SEPM-Permian Basin Section, Publication 92-33, p. 19-29.

Zhang, S. and Barnes, C.R. 2004. Arenigian (Early Ordovician) sea-level history and the response of conodont communities, western Newfoundland. Canadian Journal of Earth Sciences, v. 41, p. 843-865.

Submission date: May 11, 2010

Acceptance date: December 6, 2010

Associate Editor: Jeff Packard 